\title{
The Effectiveness of Augmented Reality Technology Based- Interactive Multimedia Implemented to Improve Students Learning Outcome Ecology at High School Level
}

\author{
$1^{\text {st }}$ Rizki A. Sambodo
}

Department of Education Science Universitas Sebelas Maret, Surakarta, Indonesia, Jl. Ir. Sutami 36 A

Kentingan Jebres Surakarta 57126

gebangtengah@gmail.com $2^{\text {nd }}$ Baskoro A. Prayitno

Department of Education Science Universitas Sebelas Maret, Surakarta, Indonesia, Jl. Ir. Sutami 36A

Kentingan Jebres Surakarta 57126

baskoro_ap@fkip.uns.ac.id $3^{\text {rd }}$ Puguh Karyantoo

Department of Education Science Universitas Sebelas Maret, Surakarta, Indonesia, Jl. Ir. Sutami 36A

Kentingan Jebres Surakarta 57126

puguhkaryanto@staff.uns.ac.id

\begin{abstract}
Augmented reality is an interactive multimedia technology that has the ability to combine virtual models in a real environment. Nowadays, augmented reality has been widely applied in the field of education and in the form of interactive multimedia. The purpose of this study is to know the effectiveness of the implementation of augmented reality-based interactive multimedia on the students' learning outcome. The research was conducted in the even semester of academic year 2016/2017 and placed in one of state high schools in Sragen. The design of this study used post only control group. This study involved 64 students divided into control class and experiment class. The students' learning outcome was measured by a multiple choice test instrument that has been valid and reliable. The test results were tested with Man-Whitney U Test assisted by SPSS 21 software. The result of statistical analysis showed that the experimental class was significantly different to the control class with Sig. value lest than $\alpha=0.05(0.00<0.05)$. Therefore, it can be concluded that the augmented reality technology based interactive multimedia effectively improve the students' learning outcome in High School Level.
\end{abstract}

Keywords- Ecology; Augmented Reality; Learning Outcome

\section{INTRODUCTION}

Ecology is a study of interactions that determine the distribution and abundance of organisms. Ecology has a wide range involving multi disciplines such as biology, physics, chemistry, geology, etc. Learning ecology not only just train students to remember and understand the materials but also able to train students' abilities to analyze and evaluate various information obtained in nature.

The students' high-order thinking on ecological material is important as it relates to their abilities to perform actions which are able to maintain the balance of nature and overcome various environmental problems arising in the increasingly complex era.

Ecological learning is ideally capable to present a wide variety of contextual information from nature. Based on Dale's statement [1], students are invited to gain hands-on experience and are engaged to act in accordance with the theories already obtained.

However, in reality, this kind of learning takes a lot of time and effort. Not all schools have access to bring students outside the school environment including SMA Negeri 2 Sragen located in urban areas. Therefore, the learning process needs to be assisted by the media that can present contextual information and simulate processes and events in real environment. One of them is multimedia augmented reality.

Augmented reality-based multimedia learning is software with the ability to generate images, sounds, 2D models, 3D models, and overlapping animations with real environments [2]. Technically Augmented reality can be used to stimulate five human senses, but generally this media is more widely used to display audio-visual multimedia information [3].

This kind of learning media has been widely applied in the world of military, medical, engineering design, manufacturing, and education. For example, Lee (2012) utilized augmented reality to simulate organs in humans. Kamarainen et al [4] integrated augmented reality with a field trip to study environmental materials. Huang, Chen, Chou [5] used augmented reality to see, feel, and provide students 
with an environmental experience. The results showed that the integration of augmented reality effectively improves the learning outcomes and student interest in the materials. Based on the background, we are interested to conduct a research entitled Interactive Multimedia Effectiveness Based on Augmented Reality Technology to Students' Cognitive Learning Outcomes in SMA Negeri Sragen.

\section{METHOD}

The research design utilizes the post only control group. The time of the study was conducted in the even semester of 2016/2017. It involves 64 students consisting of 32 control class students and 32 experimental class students. The students' learning outcome of ecology is measured by a multiple choice test instrument that has been valid and reliable. The data were tested with Man-Whitney U test which was preceded by normality and homogeneity test assisted with SPSS 21 software.

\section{RESULTS AND DISCUSSION}

\section{A. Tests of Normality}

Data analysis begins with normality test by Shapiro-Wilk at significance level $(\alpha)=0,05$. If the significance level is higher than 0.05 (Sig.> 0.05), the data indicates normal population distributions. However, if the significance is less than 0.05 (Sig. $<0.05)$, the data is not normally distributed.

Table I Tests of Normality

\begin{tabular}{cccccccc}
\hline \multirow{2}{*}{ Class } & \multicolumn{3}{c}{$\begin{array}{c}\text { Kolmogorov- } \\
\text { Smirnov }\end{array}$} & \multicolumn{3}{c}{ Shapiro-Wilk } \\
\cline { 3 - 8 } & & Statistic & df & Sig. & Statistic & df & Sig. \\
\hline \multirow{2}{*}{$\begin{array}{l}\text { Learning } \\
\text { Outcome }\end{array}$} & Experiment & .428 & 32 & .000 & .318 & 32 & .000 \\
& Control & .149 & 32 & .070 & .934 & 32 & .051 \\
\hline
\end{tabular}

a. Lilliefors Significance Correction

Based on Table 1, it is known that the results of the Shapiro Wilk test utilized SPSS 21 software obtained significance of experiment class less than $0.05(0.00<0.05)$. It can be concluded that the data is not normally distributed.

\section{B. Tests of Homogeneity}

This tests aim to test whether the variances of control and experiment class are homogeneous or not. Homogeneous variances happens if the significance is higher than 0.05 (Sig.> 0.05).

Table II Tests of Homogeneity

\begin{tabular}{lccccc}
\hline & & $\begin{array}{c}\text { Levene } \\
\text { Statistic }\end{array}$ & df1 & df2 & Sig. \\
\hline $\begin{array}{l}\text { Learning } \\
\text { Outcome }\end{array}$ & $\begin{array}{c}\text { Based on } \\
\text { Mean }\end{array}$ & 1.133 & 1 & 62 & .291 \\
\hline
\end{tabular}

Based on table II, the results of homogeneity test are obtained that the significance is at 0.291 (Sig.) $0.05)$ so it belongs to the homogeneous variance. Therefore, the two classes are considered equivalent to be compared.

\section{Tests of Hypothesis}

This tests utilize non-parametric tests by ManWhitney U Test. The criterion is Research Hypothesis (H1) should be accepted if the level significance less than 0.05 (Sig. <0.05).

Table III Man-Whitney U Tests

\begin{tabular}{cc}
\hline & Learning Outcome \\
\hline Mann-Whitney U & 204.000 \\
Wilcoxon W & 732.000 \\
Z & -4.173 \\
Asymp. Sig. (2-tailed) & .000 \\
\hline
\end{tabular}

Based on table III, it is known that the significance value (Sig.) is less than $\alpha=0.05(0.00<$ 0.05 ) so it can be concluded that $\mathrm{H} 0$ is rejected. $\mathrm{H} 1$ is accepted with the augmented-reality based interactive multimedia statements effectively improve student learning results at SMA Negeri 2 Sragen.

\section{Descriptive}

Table IV Mean Learning Outcome

\begin{tabular}{ccccc}
\hline Class & Mean & $\mathrm{N}$ & $\begin{array}{c}\text { Std. } \\
\text { Deviation }\end{array}$ & $\begin{array}{c}\text { Std. Error of } \\
\text { Mean }\end{array}$ \\
\hline Experiment & 17.75 & 32 & 10.411 & 1.840 \\
Control & 13.53 & 32 & 2.257 & .399 \\
Total & 15.64 & 64 & 7.769 & .971 \\
\hline
\end{tabular}

Table IV shows the mean scores of control and experiment classes. The mean of experiment class with the augmented reality media gains score 17,75 , meanwhile the mean of control class with conventional learning is 13,53 . The mean scores show that the acquisition score of learning result by the experiment class is higher than the control class so that learning by augmented reality media provides the higher cognitive result.

The results of this study are similar to the research conducted by Huang, Chen, \& Chou [5] which concluded that the implementation of Eco Discoverybased augmented reality effectively improves student learning outcomes. Cieza \& Lujan (2018) states that the improvement of student academic performance by augmented reality media is up to $27.6 \%$. Similarly, the research conducted by Jamali, Shiratuddin, Wong, \& Oskam [6] shows that augmented reality media has positive impacs on student learning progress.

Augmented reality is able to present virtual-actual interaction so improving student's interest and pleasure while studying [5]. Interactive learning processes reinforce personal experiences that will strengthen understanding [7]. 


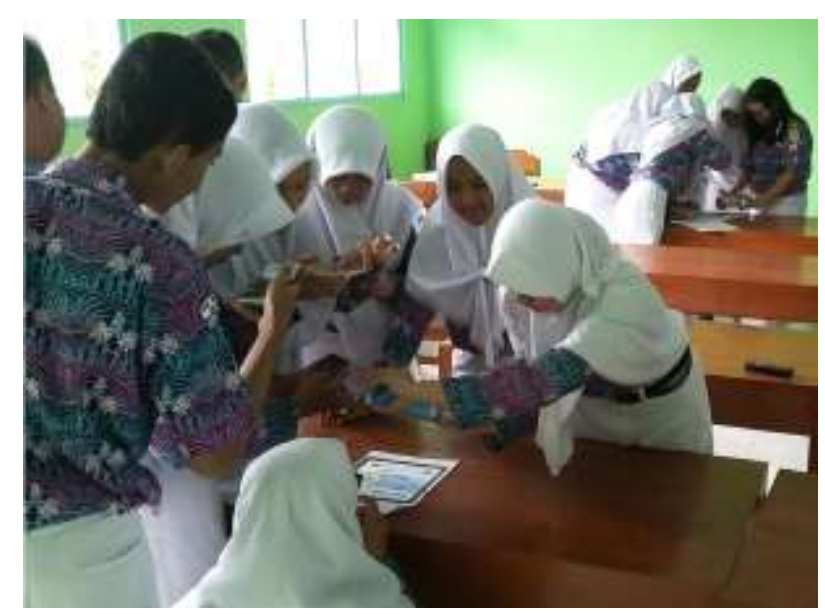

FIGURE 1. Learning activity

\section{CONCLUSION}

The result of the students' control class gain score 13.53 while the experiment class is 17.75 . The score difference is 4.22 points. The test results of different Man-Whitney $U$ Test shows that the significance value is less than $\alpha=0,05(0,00<0,05)$ so that it can be concluded interactive multimedia based on augmented reality technology effectively improve student cognitive learning results in SMA Negeri Sragen.
[1] E. Dale, Audio-Visual Methods in Teaching, 3rd ed, New York: Holt, Rinehart \& Winston, 1969.

[2] K. J. Carlson and D. J. Gagnon, "Augmented Reality Integrated Simulation Education in Health Care," Clinical Simulation in Nursing , pp. 123-127, 2016.

[3] G. Kipper, Augmented Reality, Tokyo: Syngress, 2013.

[4] A. M. Kamarainen, S. Metcalf, T. Grotzer, A. Browne, D. Mazzuca, T. M. Shane and C. Dede, "EcoMOBILE: Integrating augmented reality and probeware with environmental education field trips," Computers \& Education, pp. 545-556, 2013.

[5] T.-C. Huang, C.-C. Chen and Y.-W. Chou, "Animating Eco-Education: To See, Feel, and Discover in an Augmented Reality-Based Experiential Learning Environment," Computers \& Education 96, pp. 72-82, 2016.

[6] S. S. Jamali, M. F. Shiratuddin, K. W. Wong and C. L. Oskam, "Utilising Mobile-Augmented Reality for Learning Human Anatomy," Procedia, pp. 659-668, 2015.

[7] R. W. Clark, M. D. Threeton and J. C. Ewing, "The potential of experiential learning models and practices in career and technical education \& career and technical teacher education," Journal of Career and Technical Education, pp. 66-69, 2010.

[8] E. Cieza and D. Lujan, "Educational Mobile Aplication of Augmented Reality Based on Markers to Improve the Learning of Vowel Usage and Numbers for Children of a Kindergarten in Trujillo," Procedia Computer Science 130, pp. 352-358, 2018 .

\section{REFERENCES}

